\title{
The Strategic Planning of a Corporate Welfare System for Higher Productivity: Based on the Case Study of Korea Telecom
}

\author{
CHA, MAENG JIN \\ Advanced Center for Administrative Development \\ Graduate School of public Administration \\ Seoul National University
}

\begin{abstract}
The policy about the corporate welfare in Korea, since the economic development plan started from 1960, was focused on stabilizing the employee's livelihood and permitting only a few percentage increase annually. However, the corporate sector experienced considerable expansion of welfare needs in the latter half of the 1980 s, which consequently became a burden to the corporates.

This paper is prepared for the proper handling of the welfare problem each of the Korean corporates faces these days. In preparing this paper, the Japanese "synthetic welfare plan for employee's lifetime" was very helpful and many of the terms and contents of the plan were cited for the purposes of analysis and adaptability to Korea. The welfare plan proposed herein is designed in details so as to satisfy each employee generation's welfare needs and to provide the management of the corporate with the ability to control the overall welfare cost. With this new plan, we believe Korea Telecom would enhance the productivity of its labor force at the reasonable cost.
\end{abstract}

Key words: welfare plan, corporate welfare vision, cost control

\section{Introduction}

As people live longer, continue to alter their lifestyles and their patterns of work, they become more interested in the welfare systems of the corporate they are with. In other words, keeping pace with trend, i.e., operating its welfare systems efficiently to meet both the employee's expectations and the employer's support limitations is 
always a challenge each of the corporates faces. And more, this becomes a problem that the society, not a corporate alone, should solve to those countries the standard of living of whose people is changing and upgrading so rapidly like Korea.

With these in mind, the paper is prepared to review the riverse and well-defined theories and practices of this field and to propose a Korean-styled welfare model based on the case study of Korea Telecom. The Korean society has newly experienced the spouting of various class needs and has seen how they are accommodated into it through some social movements for democracy since $1980 \mathrm{~s}$.

Nowadays, most of the corporates in Korea have a problem in meeting these needs because it requires a considerable cost for the part of the corporates. In Korea Telecom, for instance, the increase rate of welfare expenses is $3.2 \%$ higher on the average than that of the revenues from the year 1982 to 1991 , expecially $4.2 \%$ higher since 1987. The welfare model presented in the paper is meant for the manages of the corporates who are placed in the dilemma between the employee's request for better working conditions and the corportate's accommodation of the request at as lower cost as possible, for the excessive increase of these costs would hamper the growth of the corporate.

For the presentational purpose, the paper will show first what the corporate wclfare is, the history of welfare level in Korea, and changes of circumstances in the corporate welfare. And then it will precede to the current structure of the corporate welfare system in Korea. Finally and most importantly, the new welfare plan for Korea Telecom along with the life cycle welfare concepts will be presented. Also in it is the welfare vision of employee's life cycle in Korea Telecom.

The concept of the lifetime welfare and the plan to carry out it will be presented in the paper and will be analyzed for its adaptability to Korea Telecom. And finally, the strategic corporate welfare model will be brought out for Korea Telecom and other corporates in Korea.

〈the differences between salaries and corporate welfare〉

\begin{tabular}{lll}
\hline \multicolumn{1}{c}{ Standards } & \multicolumn{1}{c}{ Salaries } & Corporate welfare \\
\hline $\begin{array}{l}\text { The relations of qualities } \\
\text { and quantities of labor }\end{array}$ & having far-reaching effect upon & not available \\
How to receive it & compensation for person & compensation for group \\
usage & unconditioned & conditioned \\
Character of income & real income & expectation income \\
How to pay & cash & various method \\
function & Improving living conditions & security of living \\
\hline
\end{tabular}




\section{Changes of Circumstances in the Corporate Welfare}

\section{The general definition of corporate welfare}

Corporate welfare is regarded as the affair of labor management that carries out attaining its objectives at its own charge and under the corporate responsibility and it consists of fringe benefits, facilities and activities for employee's welfare but labor conditions such as salary, working hours.

\section{The history of welfare-level in Korea}

\begin{tabular}{|c|c|c|c|}
\hline classification & economic condition & Ideology & The content of corporate welfare \\
\hline $\begin{array}{l}\text { The first stage } \\
\text { (befor 1976) }\end{array}$ & $\begin{array}{l}\text {-The national income per capita } \\
\text {-below } \$ 1,000 \\
\text {-The supply surplus of labor force }\end{array}$ & Paternalism & $\begin{array}{l}\text {-Supporting means of living } \\
\text { (dormitory, meals, uniform) }\end{array}$ \\
\hline $\begin{array}{l}\text { The second } \\
\text { stage (1977- } \\
1986)\end{array}$ & $\begin{array}{l}\text {-The national imcome per capita } \\
-\$ 1,000-\$ 3,000 \\
\text {-The expansion of the heavy } \\
\text { chemical industry } \\
\text { - Security and stability needs }\end{array}$ & Paternalism & $\begin{array}{l}\text {-The introduction of medical } \\
\text { (care) insurances } \\
\text { - The enlargement of social } \\
\text { welfare }\end{array}$ \\
\hline $\begin{array}{l}\text { The third } \\
\text { stage } \\
(1987-1990)\end{array}$ & $\begin{array}{l}\text {-The national income per capita } \\
-\$ 3,000-\$ 5,000 \\
\text {-The sprouting of welfare needs }\end{array}$ & $\begin{array}{l}\text { The support to } \\
\text { stabilize a sound } \\
\text { labor-manage- } \\
\text { ment relation }\end{array}$ & $\begin{array}{l}\text { - The introduction of the natural } \\
\text { welfare pension } \\
\text {-To support making employee's } \\
\text { fortune }\end{array}$ \\
\hline $\begin{array}{l}\text { The fourth } \\
\text { stage } \\
\text { (1991-1996) }\end{array}$ & $\begin{array}{l}\text {-The change of economic growth } \\
\text { policy } \\
\text { (one way to economic growth } \\
\rightarrow \text { the harmony of growth and } \\
\text { stability) } \\
\text {-The national income per capita } \\
-\$ 5,000-\$ 10,000 \\
\text {-The pursuit of leisure life }\end{array}$ & $\begin{array}{l}\text {-The rationali- } \\
\text { zation of } \\
\text { management } \\
\text {-The welfare } \\
\text { society } \\
\text { - The efficiency } \\
\text { of welfare } \\
\text { system } \\
\end{array}$ & $\begin{array}{l}\text {-Employment Insurance } \\
\text {-Corporate pension plan } \\
\text {-Welfare plan classified by } \\
\text { employee's life-cycle }\end{array}$ \\
\hline $\begin{array}{l}\text { The fifth } \\
\text { stage } \\
\text { (after 1997) }\end{array}$ & $\begin{array}{l}\text { - The national income per capita } \\
\text {-above } \$ 10.000 \\
\text { - Saturation stage of welfare } \\
\text {-The demand surplus of labor } \\
\text { force } \\
\text {-The increase of self-realization } \\
\text { needs }\end{array}$ & $\begin{array}{l}\text {-Welfare } \\
\text { improvement } \\
\text { responed to } \\
\text { employee's } \\
\text { life stage }\end{array}$ & $\begin{array}{l}\text {-Leisure, Recreation } \\
\text {-Self-realization } \\
\text {-Life long education } \\
\text {-Self-reliant welfare plan }\end{array}$ \\
\hline
\end{tabular}




\section{Changes of circumstances in the corporate welfare}

< Trend of welfare emvironments since 1980 decades>

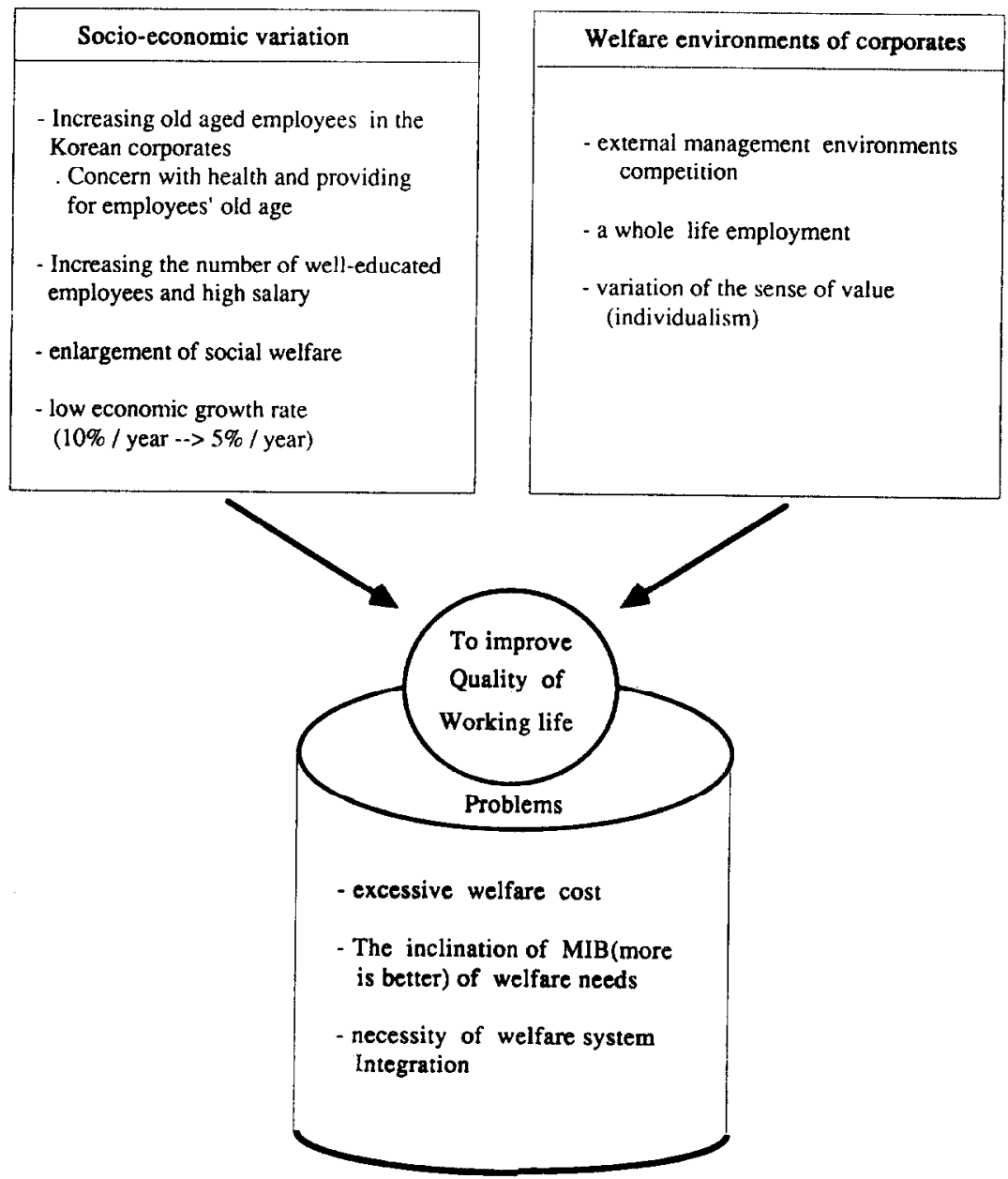




\section{The Current Structure of Corporate Welfare System in KOREA}

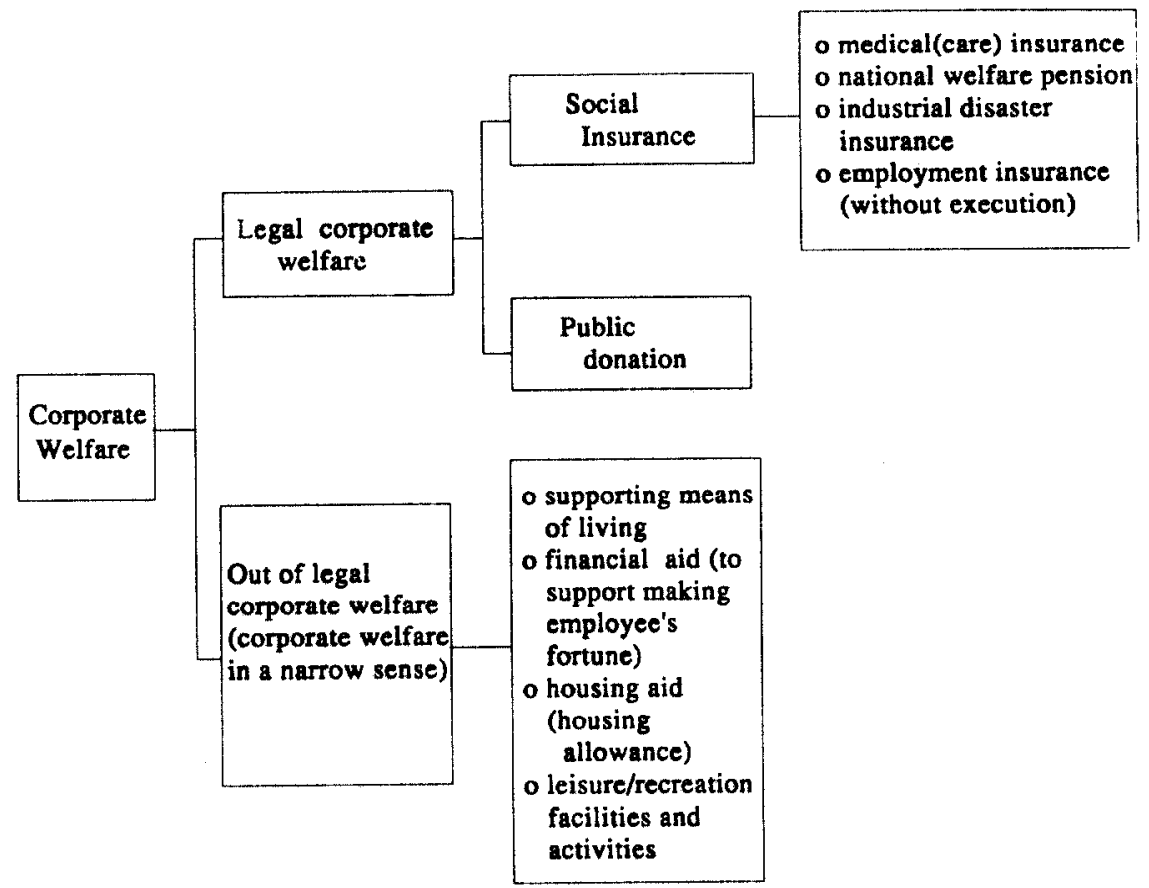

*employees want to support employees desire that the housing aid be supported more than any other aid be after 1990 .

*The expansion of employee's recreational needs.

IV. The Desirable Strategy to Raise the Efficiency of Corporate Welfare in Korea Telecom

\section{The execution procedure and meaning of life cycle welfare vision}

\section{- meaning}

According to the variation of social consciousness, if a program in the welfare plan is of no use any more, it will be abolished and combined with another. Then, satisfying with employee's new needs we can adequately control the hole welfare cost.

Therefore corporate has to take the plan which can satisfy employee's needs for life stage. 


\section{- Procedure}

The flow to design the welfare vision of employee's life cycle in Korea Telecom

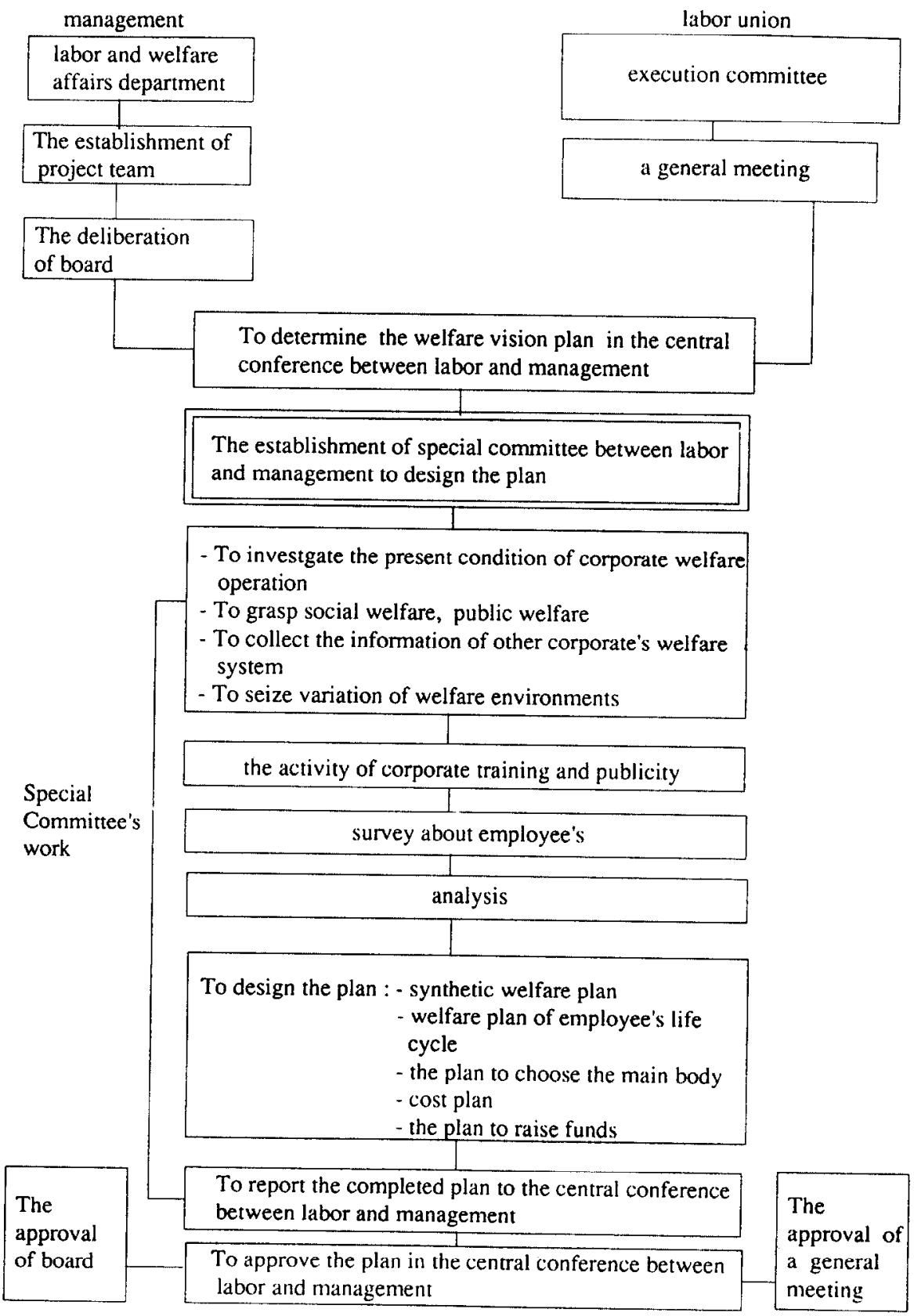




\section{The desirable strategy to ralse the efficiency of corporate welfare in Korea Telecom}

(1) environmental analysis

The periodic flow of welfare environments

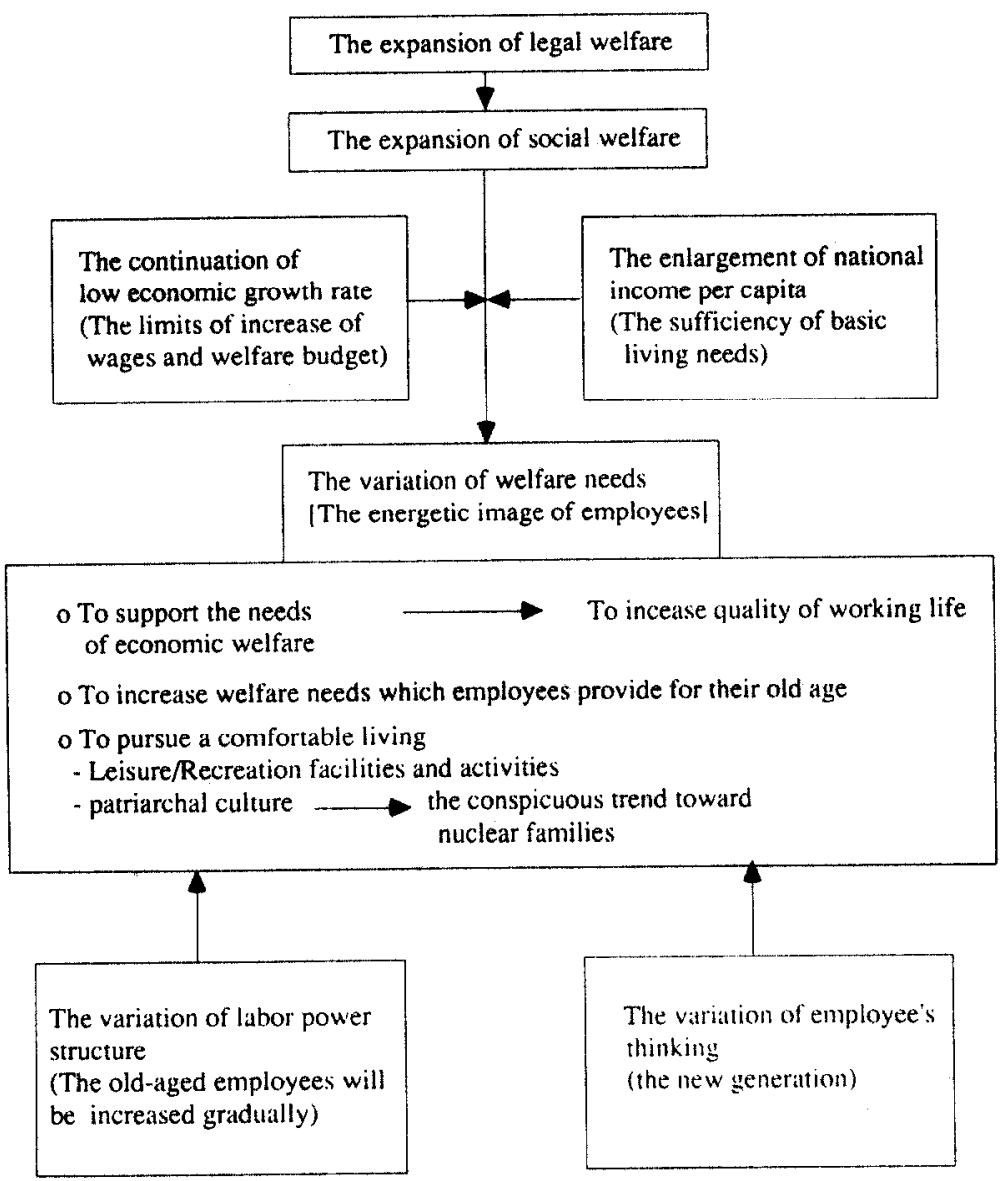


(2) The principle of practice

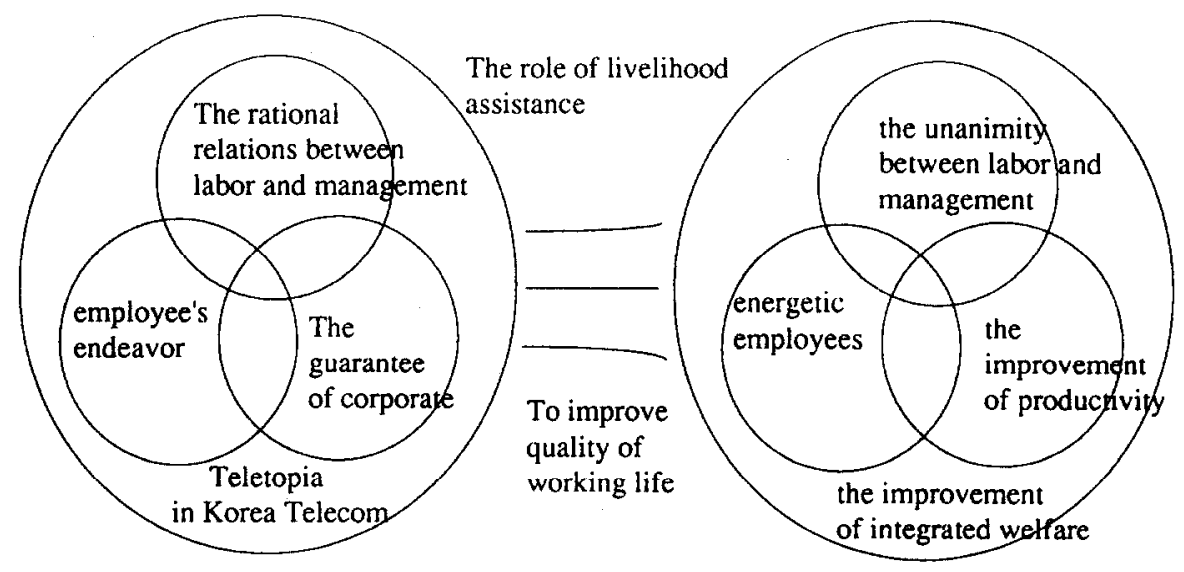

(a) The role of livelihood assistance makes employees satisfactory in the basic necessities of life

(b) The unanimity between labor and management makes employees vivacious in the working life

(c) A life worth while to live makes employees pleasant through self-realization

\section{The welfare vision system in Korea Telecom (a draft)}

Referring to Maslow's theory of Need Hierarchy and Alderfer's ERG (existence, relatedness, growth) theory, this welfare vision system could reflect the specific welfare environments of K.T. (Korea Telecom) through employee's needs survey. 
(1) The welfare vision of Korea Telecom

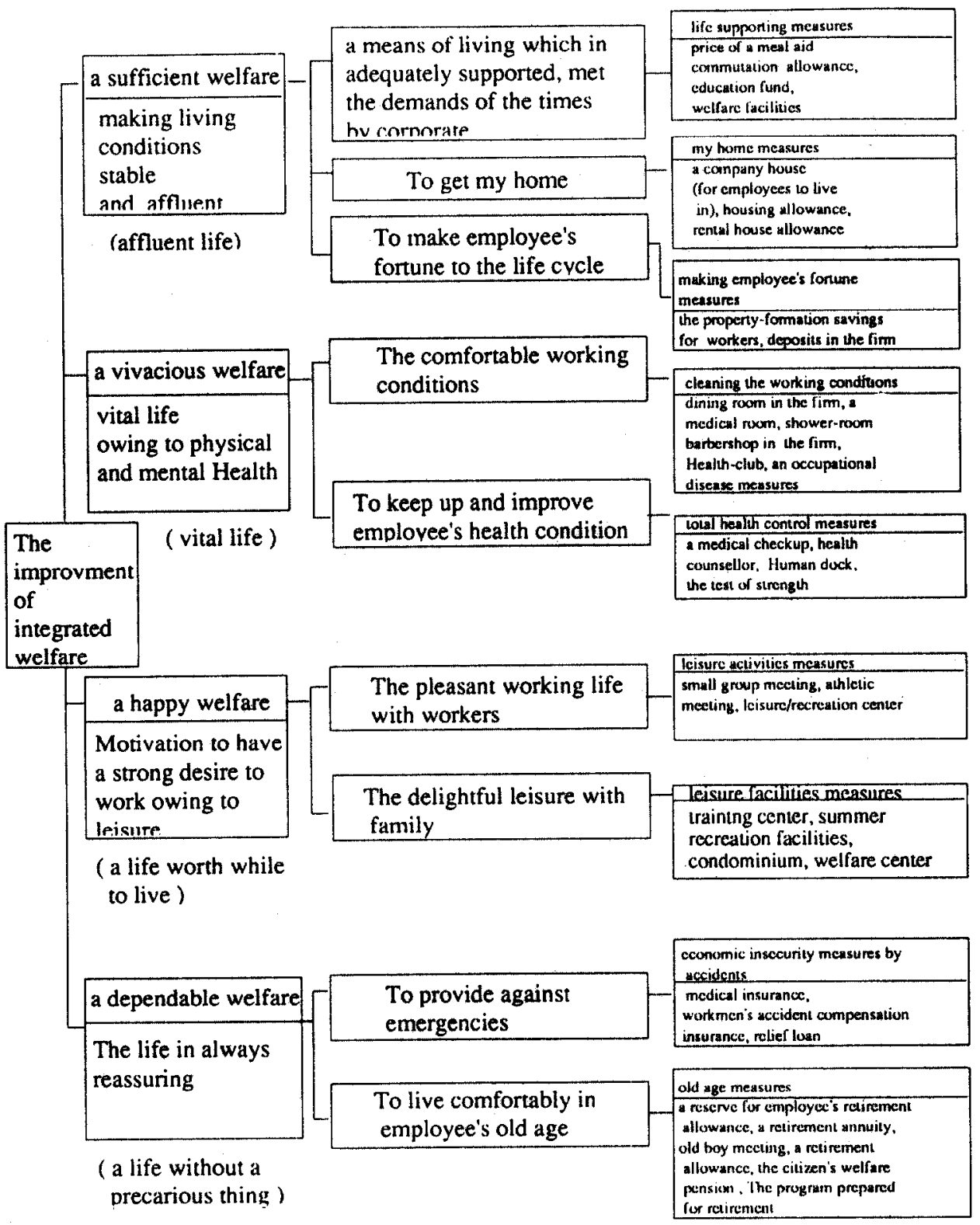

(2) Life cycle Model and welfare plan in Korea Telecom

This paper classified employees needs of life cycle into 3 dimensions through 

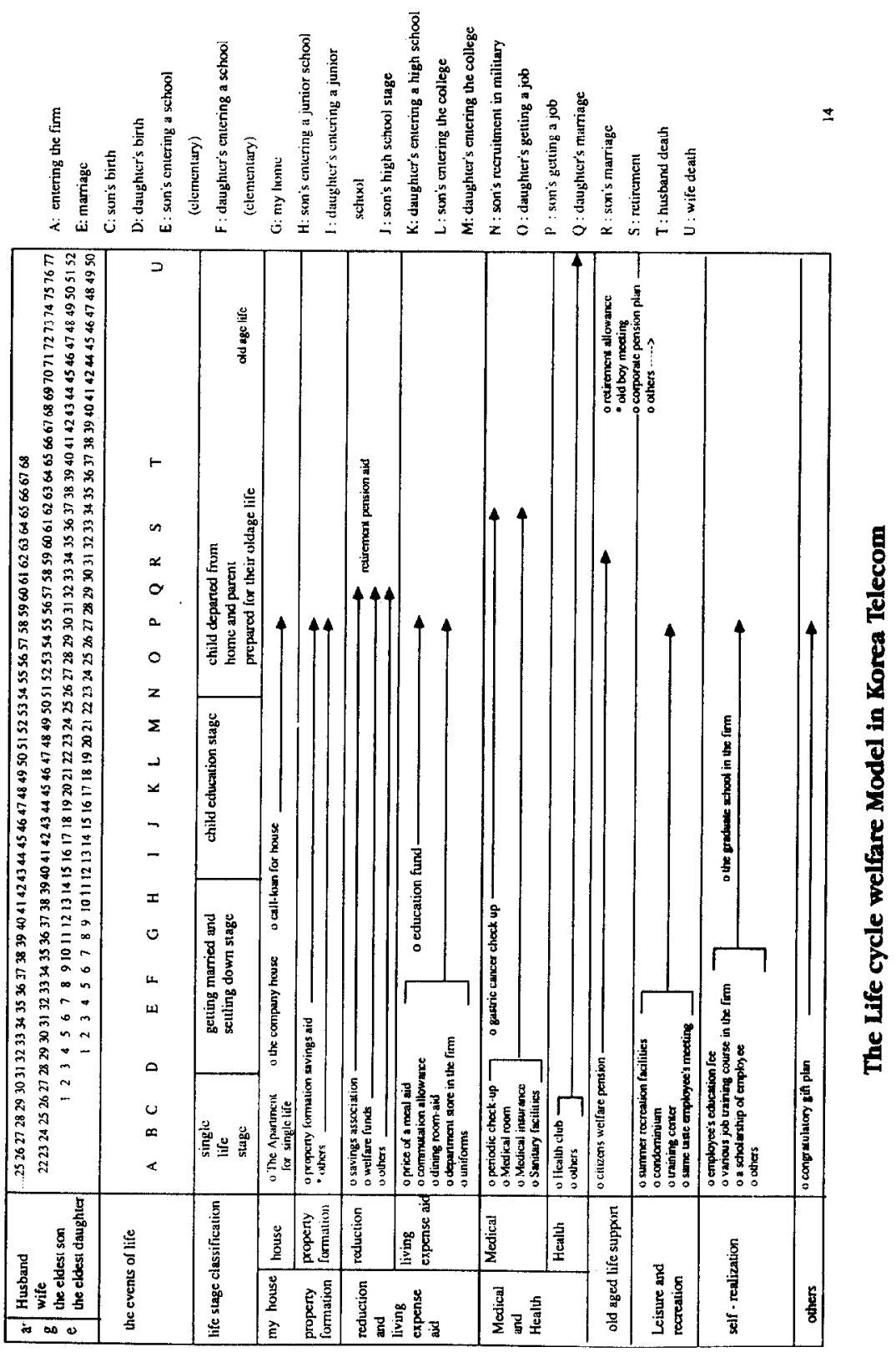
employee's welfare survey

(a) grouping method of age

(b) grouping method of sex

(c) grouping method of events (such as, marriage, the time of getting my home) therefore, this paper designed Life cycle welfare Model in Korea Telecom as follows:

\section{v. Conclusion}

Consequently, if Korea Telecom takes in the Life cycle welfare Model, it can presumably cut down about 1 hundred billion won of the welfare expenses From 1 hundred and sixty billion won to 5 hundred and sixty billion won in the early boat of the 21th century At the same time, this plan can make employees statisfactory Because it provides adequate programs at the stage situation on the employee's life cycle. Therefore, taking this Life cycle Model into consideration to their welfare plan, most corporates in Korea will accomplish their welfare objectives to raise their productivity through welfare cost control. 